\title{
Acute Toxicity of Jatropha Curcas L. Latex and Its Histopathological Effects on Dental Pulp and Periapical Tissues
}

\author{
Fazwishni Siregar $^{1^{*}}$ and Rini Damayanti ${ }^{2}$ \\ ${ }^{1}$ Senior lecturer. Faculty of Dentistry, Universitas YARSI, Jakarta, Indonesia \\ ${ }^{2}$ Indonesian Research Center for Veterinary Science (BB Litvet), Bogor, Indonesia
}

\begin{abstract}
Traditional uses of Jatropha curcas L. latex,among others, are to cure toothache. This study aimed to evaluate the acute toxicity of $J$. curcas latex by oral route and to assess the histopathological effects of $J$. curcas latex on dental pulp and periapical tissues. For acute toxicity, the latex of $5 \mathrm{~g} / \mathrm{kg}$ BW was administered intragastrically to the test groups of albino mice and water to the control groups. The assessment was based upon mortality, sign of toxicity, body weight, and histological evaluation of organs. Results showed no mortality in mice up to $5 \mathrm{~g} / \mathrm{kg}$ body weight, no sign of toxicity, and no tissue alterations macroscopically and histopathologically were observed. There's no significant difference in body weight between the test and control, both in male and female groups. For testing histopathologic effect on dental pulp, the latex was brought in contact with dental pulp and sealed. The assessment was based on the presence of inflammation and necrosis in dental pulp and periapical tissues, histopathologically. Results showed inflammation and necrosis, which was in direct contact with the latex were observed in a limited area, while underneath was normal pulp. No inflammation or necrosis in periapical tissues was observed in all groups. It caused coagulative necrosis in the pulp which was in direct contact with latex. It can be concluded that $J$. curcas latex is slightly toxic to mice at a single dose of oral administration. Inflammation and necrosis are observed on dental pulp which is in contact with latex while the tissue underneath is normal. It did not caused inflammation on periapical tissues.
\end{abstract}

Keywords: traditional medicine; acute toxicity; Jatropha curcas latex; tooth ache; effect on dental pulp and periapical tissues.

\section{INTRODUCTION}

Jatropha curcas is a small tree belonging to the family of Euphorbiaceae. It is a nature of tropical America, but now thrives in many parts of the tropic and subtropic of the world (Li et al., 2010). It is widely cultivated for biodiesel fuel plant. Beside it, J. curcas has been reported to have a lot of health benefits and used as a traditional medicine in many developing countries. The name Jatropha curcas means Doctor's nutrient. Its leaves, oil, and sap are used for medicinal use.

The sap from the bark is used to dress bleeding wounds and ulcers, and to treat toothache (Agbogidi et al., 2013). In Northeast India, the latex is used as a traditional medicine in 8 ailments (Goswani et al., 2013). In Indonesia and The Philippines, Jatropha curcas (the Indonesian local name is jarak pagar) latex is used among others to relieve dental pain, stomatitis aphtosa, and to stop wound bleeding. In Peru, the latex is used as an anti-inflammatory by massaging the traumatic area (de Feo, 1989).

For a subject that will be used as dental materials, it should pass a series of biological tests.

\footnotetext{
*Corresponding author : Fazwishni Siregar

Email : fazwishni.siregar@gmail.com
}

The first stage is safety evaluation including cytotoxicity, acute toxicity, mutagenicity, and sensitivity tests, the second stage is it used in animal as its usage in human (ISO 7405, 1984). Some preliminary works had been done on the $J$. curcas latex. Phytochemical screening identified the main chemical compounds in J. curcas latex which are sterols, flavone aglycones in ether extracts, tannins, reducing compounds, sterol glycosides in the ethyl extract, and tannins, reducing compounds, poliose, saponins in the aqueous extract (Siregar et al., 2001). Besides saponin and tannins, the latex also contains wax and resin (Perry and Metzger, 1980; Watt and Breyer-Brandwick, 1932).

Several studies have been carried out on latex of J. curcas. MTT test revealed that the latex is cytotoxic to fibroblast cell and epithelial cells in dose-dependent manner (Siregar and Akbar, 2000; Dewi Fatma et al., 2012). A cytotoxic study by agar overlay showed that the latex coagulates the cells and not lyse the cells (Siregar, 2015). The mutagenic assay showed that it is not mutagenic (Siregar and Kristiani, 2007). The latex has coagulation effect which is shown in its ability to coagulate blood that makes it used to stop wound bleeding (Kone-Bamba et al., 1987). Studies show 
that J. curcas latex has potent antimicrobial activity against Staphylococcus aureus, Neisseria gonorrhoea, Escherichia coli, and Aspergillus flavus (Arekemase et al., 2011; Arun et al., 2012; Thomas, 1989).

The term acute toxicity indicates the toxic effect caused by a single dose of a given substance. This test is performed in animals to evaluate the toxic effect of a chemical substance that will be used for household, cosmetics, additive, medicine, and others. The main purpose of acute toxicity generally is to ascertain the lethal dose in one or more species, usually rodentia. Another purpose is to estimate the dose that caused certain toxic effect. Generally, lethal dose 50 or $\mathrm{LD}_{50}$ is confirmed which define as a single dose of a chemical substance that killed $50 \%$ of experimental animals statistically (Balasz, 1977; $\mathrm{Lu}, 2010$ ).

After the first stage of biological testing on dental materials, the second stage should be done on an animal as its usage in humans. The latex of $J$. curcas is used traditionally among others is to relieve dental pain. Toothache usually has throbbing pain or pain when drinking cold water which is the sign of pulpitis. To relieve dental pain in toothache, a drop of fresh latex from the stalk leaves was put on a small cotton ball and insert into the tooth cavity.

The first objective of this study was to assess the acute toxicity of latex after a single dose of oral administration. The second objective was to evaluate the in vivo histopathological effects of $J$. curcas latex on healthy dental pulp and periapical tissues in animal as it is used in human as the second stage of biological tests.

\section{METHODOLOGY}

To standardize the sample, Jatropha curcas latex was collected by incising the young bark of plants grown at Research Center on Herbal Medicine and Spices (Balai Penelitian Tanaman Rempah dan Obat, Balittro), Bogor, Indonesia. The $\mathrm{pH}$ of latex obtained was 3.49. After freeze-drying for 50 hours, the latex was stored at $-20^{\circ} \mathrm{C}$. The mean of dry weight/volume obtained was $15 \%$. This freeze-dried latex was used as a test sample throughout the experiments.

\section{Methods for Acute Toxicity}

Male and female albino mice (from The National Quality Control Laboratory of Drug and Food, Indonesia) with the bodyweight range of 2023 grams were used for this test. They were fed with a standard laboratory diet and water ad libitum. The mice, male and female separated, were allocated at random to test or control groups of 5 mice. Latex was dissolved in water and administered using an intragastric needle to the test group while the same volume of aquadest was administered to the control group. The range of doses selected for the final assay was delineated by the highest dose that did not cause death and the lowest dose that caused death in all animals. This range would be divided into five equal logarithmic intervals. For a pilot test, dosages of 1 and $5 \mathrm{~g}$ freeze-dried latex per kg body weight were given to the test groups. The pilot test with albino mice showed no mortality on a single oral administration of 1 and $5 \mathrm{~g} / \mathrm{kg}$ body weight dried latex of Jatropha curcas. While the maximum amount of latex that could be dissolved in water was $500 \mathrm{mg} / \mathrm{ml}$ and the maximum volume that could be administered intragastrically was $1 \mathrm{ml}$ per 100 grams of body weight. Hence, the acute toxicity test was performed with single highest dose that could be given which was $5 \mathrm{~kg} / \mathrm{kg}$ body weight. The randomized controlled experiment was performed on male and female groups of 5 albino mice.

Observation of toxicological signs and death at 1,2 , and 4 hours were made following administration and followed with 2 weeks of daily observation. The animals were weighed daily. After two weeks of observation, the animals were sacrificed and examined at necropsy. The liver, kidneys, intestine, stomach, spleen, and heart, were examined macroscopically and histopathologically and compared between groups. The assessment of the test was based upon a comparison between the test group and the control group concerning mortality, signs of toxicity as activity, diarrhea, spasm, dyspnea, piloerection, weight gain and loss data, and histologic evaluation of organs (Balasz,1970; Weil, 1952; ISO 7405, 1984).

\section{Methods for Histopathological Effects on Dental Pulp and Periapical Tissue}

All erupted and intact teeth from four female Macaca fascicularis monkeys were used for this study. Ethical clearance was performed in front of the Institutional Animal Care Committee (IACUC) at Primate Research Center Bogor Agricultural University. All experimental procedures were performed under general anesthesia with ketamine. Before the procedures, the teeth, and surrounding tissues were cleaned and disinfected with a $10 \%$ povidone-iodine solution. Using diamond bur underwater mist, an appropriate cavity was made into the tooth exposing the pulp chamber. After cleaning with saline and drying the cavities by sterile cotton pellets, cotton pellets impregnated with different 
concentrations of latex $(3.7,7.5,15 \%)$ were inserted into the cavity to make contact with pulp tissues and sealed with temporary filling IRM. Except for the latex application, control teeth were prepared and sealed in the same way and all teeth were left for three days.

After sacrificing the animal and before removal of the teeth, a clinical evaluation was performed and no inflammation and abscess were found in the inspection. The teeth were removed in block section and fixed in 10\% neutral buffered formalin. Decalcification of specimens was then made in $20 \%$ formic acid at room temperature and processed for embedding in paraffin. Serial histologic section were made on tooth long axis and stained with hematoxylin-eosin. The assessment was based on the presence of inflammation and necrosis in dental pulp and periapical tissues histopathologically as written in ISO (1984) and Simon (1978).

\section{RESULT AND DISCUSSION}

Among its traditional uses, Jatropha curcas latex was used to cure toothache. The fresh latex was put into the cavity of dental caries. To consider the possible use in dentistry, many experiments should be completed and the safety level should first be determined. This is necessary because J. curcas has variable content and toxic substances in the plant. To have a homogeneous sample, latex was collected from one area in one season, then lyophilized and stored at $-20{ }^{\circ} \mathrm{C}$. For all tests, this lyophilized latex dissolved in aquadest or medium was used as the sample. Fresh latex was not used.

The safety of a chemical substance should be evaluated experimentally in animal in 3 levels that are acute, subacute, and chronic toxicity. Nowadays extend toxicity studies are performed include allergy, fertility, teratogenicity, carcinogenicity, and mutagenicity tests (Autian, 1974). In its usage to cure toothache, the latex of Jatropha curcas is used only once, put it directly into the cavity and leave overnight. For this reason, the acute toxicity in single-dose by oral administration was performed.

The result of acute toxicity of J. curcas latex by oral route was at day 1 , no mortality, diarrhea, spasm, dyspnea, and piloerection were observed in test and control groups. However, inactivity was apparent in both male and female test groups compared to the control groups. During the following 2 weeks of observation, no activity difference and signs of toxicity were seen among the groups.

Animal body weight was measured daily for 2 weeks (Figure 1 and 2). All male mice in the control group showed an increasing body weight, while 2 male mice in the test group showed no gain weight compared to others. The average \pm SD of the male mice body weight in the test group was 26.37 $\pm 4.26 \mathrm{~g}$, slightly lower than those in the control group which was $26.95 \pm 2.06$ g. However, covariant statistical analysis between the test and control male groups showed no significant difference at $p=0,643$. In female groups, the average body weight of the test group was 25.2 ? $2.36 \mathrm{~g}$, a little bit higher than those in the control group which was $24.98 \pm 1.06$ g. Covariant statistical analysis between the test and control male groups showed no significant difference at $\mathrm{p}=0.434$.

Macroscopic observation on necropsy revealed no difference in the shape, size, and color of the stomach, intestine, liver, spleen, heart, lung, and kidneys between test and control groups. No significant difference was observed between test and control groups, male and female, by microscopic examination of hematoxylin-eosin histopathologic sections.

Acute toxicity tests resulted in no mortality in mice with concentration up to $5 \mathrm{~g} / \mathrm{kg} \mathrm{BW}$ when ingested into the stomach and no tissue alteration was observed. Inactivity observed at day one was noted as a sign of toxicity. However, there was no difference the next day. Statistically, there was no difference in body weight gain; however, individual measurement on the male group recorded no weight gain in 2 mice suggesting the possibility of latex influence on body weight. Subacute and chronic toxicity studies must still be carried out to obtain more information on toxicity for short and long-term use.

As there were limitations in administering latex by the methods we used, the assumption that can be made is that the LD50 was more than $5 \mathrm{~g} / \mathrm{kg}$ body weights. According to relative toxicity, chemicals were commonly classified as super-toxic ( $5 \mathrm{mg} / \mathrm{kg}$ or less), extremely toxic $(5-50 \mathrm{mg} / \mathrm{kg})$, highly toxic $(50-500 \mathrm{mg} / \mathrm{kg})$, moderately toxic (500-5.000 mg/kg), slightly toxic (5.000-15.000 $\mathrm{mg} / \mathrm{kg}$ ), practically non-toxic (> $15.000 \mathrm{mg} / \mathrm{kg}$ ) (Autian, 1974). According to this classification, dry latex of J. curcas is slightly toxic to the mouse if given orally.

Folkloric use of this latex to cure toothache was to put a little latex on absorbent cotton and insert it to the tooth cavity. It is supposed that the amount of the latex is $0.01-0.05 \mathrm{ml}$ that was taken from the stem leaf. If this amount of latex were freeze-dried, it would yield 15\% X $0.05=0.0075 \mathrm{~g}$ dried latex. If the bodyweight of a man is $50 \mathrm{~kg}$, then he took 0.0075 per $50 \mathrm{~kg}$ or $0.00015 \mathrm{~g} / \mathrm{kg} \mathrm{BW}$. While the LD50 more than $5 \mathrm{~g} / \mathrm{kg} \mathrm{BW}$ is equal to more than $5 / 15 \times 100 \mathrm{ml}=33 \mathrm{ml}$ fresh latex per $\mathrm{kg}$ 


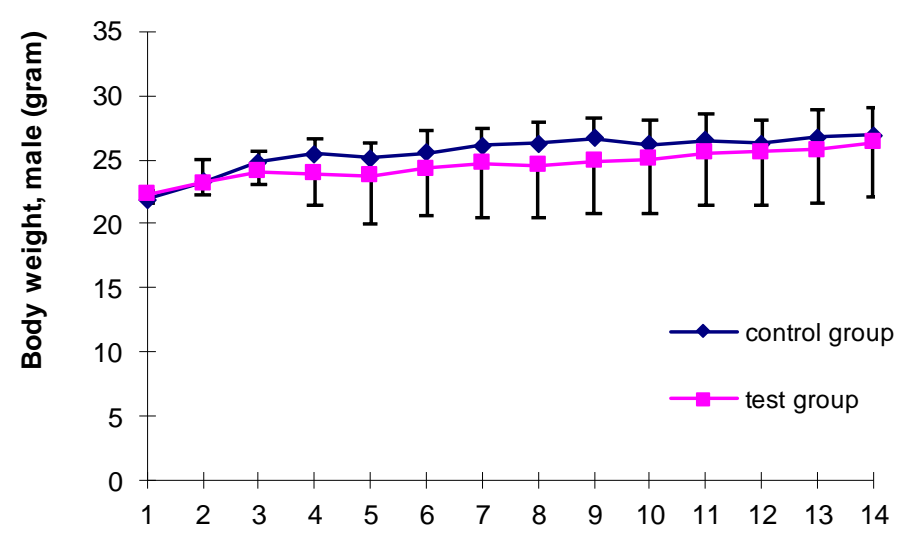

Figure 1.

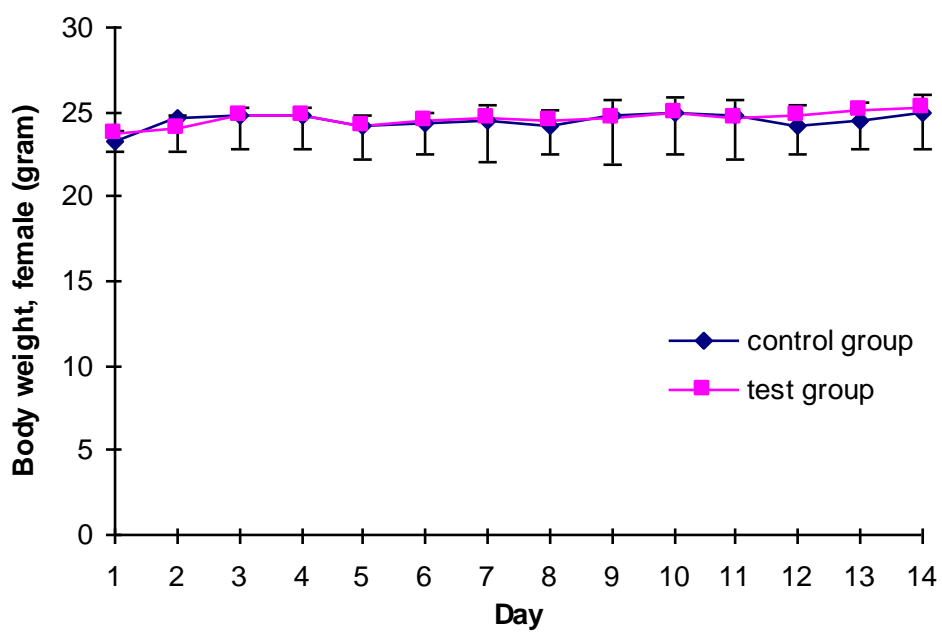

Figure 2.

Figures 1 and 2. Mean of body weight of 5 male (Figure 1) and female (Figure 2) mice of control and test groups. Mice in test groups were given a single dose of $5 \mathrm{~g}$ freeze-dried J. curcas latex per kg body weight intragastrically. Covariance statistical analysis showed no significance difference in body weight between the control and test groups at $\mathrm{p}<0.05$.

BW. It seems that a little drop of $0.05 \mathrm{ml}$ fresh latex would be safe to man if ingested accidentally.

From this study, it can be concluded that the LD50 of dried J. curcas latex is more than $5 \mathrm{~g} / \mathrm{kg}$ BW to the mouse if given in a single dose intragastrically. At dose $1 \mathrm{~g} / \mathrm{kg}$ BW there was no mortality and sign of toxicity. At dose $5 \mathrm{~g} / \mathrm{kg} \mathrm{BW}$ there was no mortality but there was inactivity as a sign of toxicity at day 1 . While at the following two weeks, there was no difference with the control group. No significant body weight gain difference observed. Neither difference was observed on the macroscopic examination or microscopic examination on the heart, lungs, liver, spleen, kidneys, stomach, and intestine.

\section{Result for Histopathological Effect on Dental Pulp and Periapical Tissues}

Histopathological examination on dental pulp revealed a limited zone of precipitation on pulp surface tissue which was in direct contact with different concentrations of J. curcas latex. Beneath, inflammation and necrosis were observed in a limited area not more than two-third of pulp chambers. Necrotic pulp tissues were observed signed by dying odontoblast cells which 


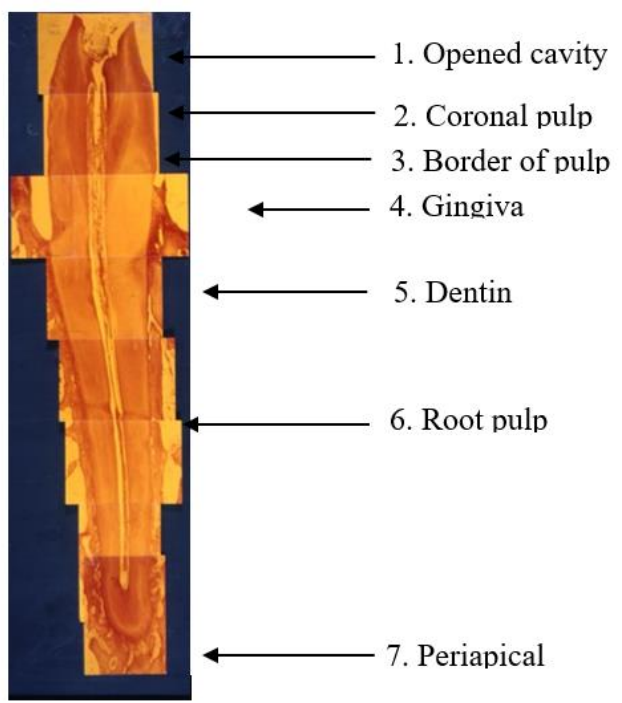

Figure 3. Photomicrograph of tooth and periapical tissues given 3.7\% J.curcas latex for 3 days. Necrotic of pulp tissue were observed in a limited area under the cavity. 1, Cavity; 2 , coronal pulp; 3 , border of pulp tissue reaction to the latex; 4, gingival sulcus; 5 , dentin; 6, root pulp; 7, periapical tissues. (X10. H\&E)

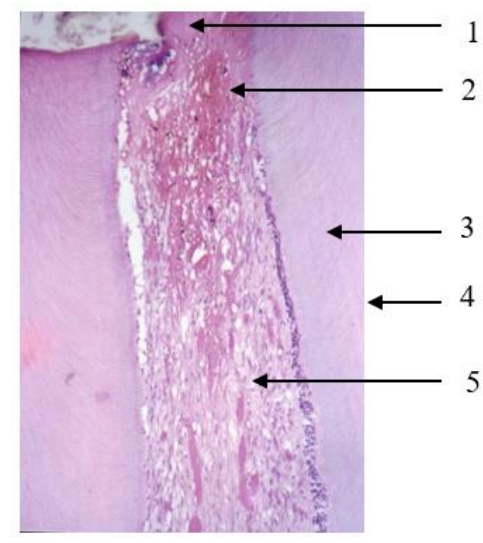

Figure 4. Photomicrographs of pulp under cavity given $15 \%$ J. curcas latex for 3 days. Necrotic pulp tissue was observed in a limited area. Normal appearing pulp tissue was seen below the necrotic zone. 1, Opened cavity; 2 , necrotic pulp; 3, odontoblast; 4, dentin; 5, normal pulp. (X30, H\&E)

were also observed in control specimens. Signs of focal inflammation with infiltration of inflammatory cells and dilated blood vessels were present in all samples. Inflammation in the pulp of the test group was not greater than that in the control group. Indeed, inflammatory cell infiltration was less in pulp treated with $15 \% \mathrm{~J}$. curcas than in the controls. Lysis of pulp was not observed. This was following the study on cytotoxicity of J. curcas latex by agar overlay technique which showed that the latex did not lyse the cells but fixed the cells. Normal appearing pulp tissue was observed below the necrotic zone. In both control and treated groups, there were no signs of inflammation or necrosis in the periapical tissues (Figure 3-5).
Folkloric use of J. curcas latex among others is to relieve pain from dental pain in carious teeth. Studies on cytotoxicity showed that J. curcas latex is cytotoxic and precipitates protein. These properties may cause coagulative necrosis of the surface of dental pulp tissue in contact with latex. Phytochemical screening test showed that latex contains tannin, which in general, is known to precipitate protein. Tannin precipitates the protein of exposed surface tissue or ulcers and promotes underlying tissue regeneration. In this study, the latex containing tannin influenced only a limited area that was in direct contact with the latex. Such a limited area consequently causes minimal if any irritation to periapical tissues. This study was performed in healthy teeth and histological 


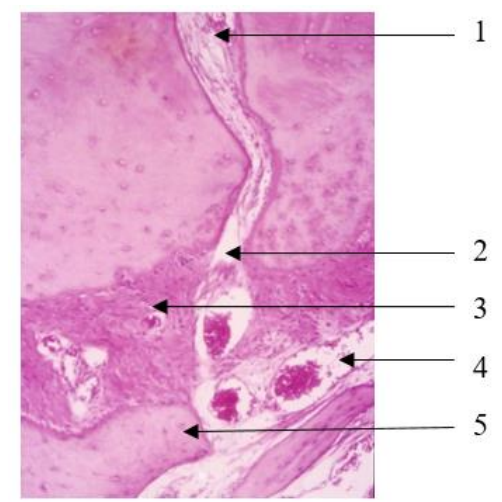

Figure 5. Photomicrgraph of periapical tissues given $15 \%$ J. curcas latex for 3 days. No inflammation was observed. 1. Radicular pulp; 2. apical foramen; 3. periodontal ligament; 4. blood vessel; 5 . alveolar bone (X70, H\&E).

examination showed only a limited necrotic area which was in contact with J. curcas latex, but the underlying tissues contained no apparent pathology.

Histological examination showed less inflammatory cell infiltration in pulp treated with latex than those observed in control specimens. Studies on J. curcas latex showed that it inhibits the release of IL-10 and collagenase (Siregar, 2000; Siregar and Akbar, 2007). This inhibition may have reduced their effect on tissues that typically activate the endothelial cells and attract inflammatory cells.

In periapical tissues, inflammation or necrosis was observed in neither the control nor experimental groups. When compared to arsenic and paraformaldehyde that irritate the periapical tissues (Simon, 1978), this is a promising finding. The effect of J. curcas latex to a limited pulp area probably could be useful as a biological dental root canal obturation for pulpotomy procedures.

\section{CONCLUSIONS}

Latex of J. curcas may be classified into slightly toxic. The dose $5 \mathrm{~g} / \mathrm{kg} \mathrm{BW}$ was equal to 33 $\mathrm{ml}$ fresh latex $/ \mathrm{kg} \mathrm{BW}$. It seems to be effective in relieving pulpal pain. It caused coagulative necrosis in pulp tissue which was in direct contact with latex, while the tissue underneath was normal. It did not cause inflammation and necrosis to periapical tissues.

\section{ACKNOWLEDGMENT}

Many thanks to Research Center on Herbal Medicine and Spices (Balittro), Bogor, Indonesia, Primate Research Center Bogor Agricultural University, and Prof. Heriandi PhD, Prof Siti M Akbar, T. Handoko, and H-J. Freisleben for their support to realize the research.

\section{REFERENCES}

Agbogidi O.M., Akparobi S.O., Eruotor P.G., 2013, Health and environmental benefits of Jatropha curcas Linn., App Sci Rep., 1(2): 3639.

Arekemase, M.O., Kayode, R.M.O., Ajiboye, A.F., 2011, Antimicrobial activity and phytochemical analysis of Jatropha curcas plant against some selected microorganisms. Int. J. Biol., 3(3): 52-59.

Arun K, Anu B, Ruchika G., 2012, A comparative study of antibacterial activity of leaves and latex of Jatropha curcas L., IJPPR; 4 (4): 190194.

Autian J. 1974, General toxicity and screening tests for dental materials. Int Dent J., 24: 235-250.

Balazs T., 1970, Measurement of acute toxicity, in Paget G.E. (Ed), Methods in Toxicology, pp. 49-81, Blackwell Sci., Publ. Oxford.

de Feo V., 1989, Uso di planti ad azione antiinflammatoria nell'Alto Ucayall, Peru Orientale, Fitoterapia, 62: 481-494.

Dewi F.S, Widurini, Farida, R., Irmaleny. 2012. In vitro cytotoxicity of Jatropha curcas in epithelial and fibroblast cells. J Nat Prod., 5: 214-221.

Goswami N.K, Saharia D., Kar A., 2013. Traditional uses of Jatropha curcas Linnaeus (Euphorbiaceae) as medicine by different communities in Northeast India, Pleione, 7: 66-72.

Heyne K. 1987, Tumbuhan Berguna Indonesia, Vol II. 1st Ed., pp. 1180-1182, Translated by Litbang Kehutanan, Jakarta.

International Standard Organisation (ISO), 1984. Biological Evaluation of Dental Materials, Technical Report \# 7405.

Kone-Bamba, D., Pelissier, Y., Ozoukou, Z.F., and Kouao, D., 1987., Haemostatic activity of 
fifteen medicinal plants of the traditional medicine of the Ivory Coast, Plant. Med. Phytother, 21: 122-130.

Li C.Y., Devappa R.K., Jian-Xin Liu JX, Lv J.M., Makkar H.P.S., Becker K., 2010., Toxicity of Jatropha curcas phorbol esters in mice.,Food Chem Toxicol., 48: 620-625.

Lu F.C., 2010, Toksikologi Dasar. Azas, organ sasaran, dan penilaian risiko.Terjemahan. 2nd ed., pp. 85-97, UI Press, Jakarta.

Prasad D.M.R., Izam A., Khan M.M.R., 2012, Jatropha curcas: Plant of medical benefits. $J$ Med Plant Res., 6: 2691-2699.

Simon, M., 1978, Tissue fixation and response after the application of devitalizing pastes containing formaldehyde, J. Brit. Endodont. Soc., 11: 71-76.

Siregar F, Akbar S.M.S., 2000, Cytotoxicity of Jatropha curcas (Euphorbiaceae) latex on fibroblast by MTT assays. Med J Indones., 9: 253-257.

Siregar, F., 2000, Biological study on the effect of Jatropha curcas latex on tooth and its supporting tissues. Disertation,Universitas Indonesia, Jakarta.

Siregar F.S., Akbar S.M.S., Chairul, 2001, Phytochemical screening and hemolytic activity of Jatropha curcas (Euphorbiaceae) latex. Proceeding International seminar on natural products chemistry and utilization of natural resources. Depok, pp. 326-332.

Siregar, F., Akbar S.M.S., 2007, Jatropha curcas latex inhibits the release of collagenase by gingival fibroblast, Med. J. Indones., 16(4): 219-223.

Siregar F, Kristiani, 2007, Mutagenicity activity of Jatropha curcas L (Euphorbiaceae) latex, Period Kedokteran Sci., 39: 23-26.

Siregar, F., 2015, Cytotoxicity of physic nut (Jatropha curcas L., Euphorbiaceae) latex by agar overlay. Jurnal Kedokteran Yarsi; 23(5): 143-148.

Thomas 0.0., 1989, Re-examination of the antimicrobial activities of Xylopia aethiopica, Carica papaya, Osinum gratisimum and Jatropha curcas. Fitoterapia, 60: 147-155.

Watt J.M., Breyer-Brandwick M.G., 1932, The Medicinal and Poisonous Plants of Southern and Eastern Africa, p 302, E\&S. Livingstone, Edinburg.

Watt J.M., Breyer-Brandwick M.G., 1962, The Medicinal and Poisonous Plants of Southern and Eastern Africa, pp. 420-422, E\&S. Livingstone, Edinburg.

Weil C.S., 1952, Tables for convenient calculation of median-effective (LD50 or ED50) and instructions in their use, Biometrics, 8: 249261. 